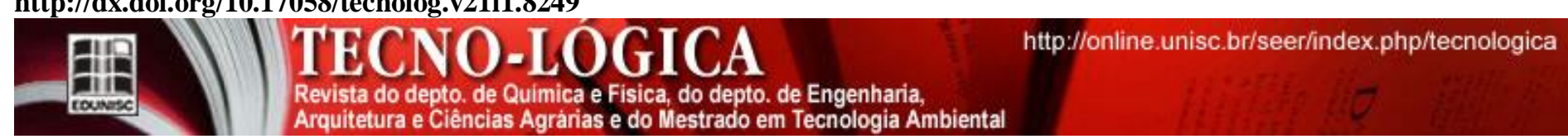

\title{
INFLUENCE OF MILLING PARAMETERS IN THE MORPHOLOGY OF NANOSTRUCTURED CrC-30wt\% NiCr
}

\author{
Waleska Campos Guaglianoni ', Ana Paula Garcia ${ }^{1}$, Regina Felisberto ${ }^{l}$, Tania Maria Basegio ${ }^{\prime}$, Carlos Pérez Bergmann \\ ${ }^{I}$ Departamento de Materiais, PPGE3M, Universidade Federal do Rio Grande do Sul, 90035-190, Porto Alegre, Brazil.
}

*E-mail: waleskaguaglianoni@yahoo.com.br

Recebido em: 07/09/2016

Aceito em: 07/11/2016

\begin{abstract}
Nanostructured $\mathrm{CrC}-30 \mathrm{wt} \% \mathrm{NiCr}$ powders were synthesized by high energy ball milling in a planetary ball mill. Two ball-topowder ratios, four milling times and two milling speeds were used. Morphology, average grain diameter, and phase transformation of the powders were characterized by scanning electron microscopy (SEM), particle size analysis, and X-ray diffraction (XRD). Crystallite size and mean diameter decrease with increase in BPR, milling time and speed. The results show that with the use of a ballto-powder weight ratio of 1:20, a milling time of $1 \mathrm{~h}$ and a milling speed of $500 \mathrm{rpm}$, the average particle size and crystallite size were respectively $5.6 \mu \mathrm{m}$ and $8.3 \mathrm{~nm}$.
\end{abstract}

Keywords: CrC-30wt\%NiCr. Nanostructured. High energy ball milling. Morphology.

\section{Introduction}

Mechanical alloying (MA) is a high-energy ball milling technique used to produce a variety of materials, such as borides, carbides, nitrides [1], oxides and nanocomposites [2]. Refinement of grain sizes down to nanometer range can be achieved by MA [3]. Nanostructured powders produced by MA possess physical and mechanical properties different from those of materials prepared by conventional techniques [4]. Nanocomposites with high strength, fracture toughness, stiffness, wear resistance and high-temperature properties are potential candidate materials for structural applications in aerospace hardware and turbo engine parts and pumps [5].

The final constitution of the powder is affected by milling parameters, such as type of mill, milling speed, milling time, ball-to-powder weight ratio (BPR), type, size, and size distribution of the grinding medium [6]. Recent studies assessed the influence of milling parameters in the morphology of chromium carbides obtained by MA. Tao et al [7] synthesized nanocrystalline $\mathrm{NiCrC}$ alloy powders using cryogenic ball milling and investigated the influence of the milling time in nanocomposite microstructure. Huang and McCormick [8] used chromium and carbon powders to obtain chromium carbides, $\mathrm{Cr}_{7} \mathrm{C}_{3}$ and $\mathrm{Cr}_{3} \mathrm{C}_{2}$. The effect of the milling time and collision energy (directly related to the type of mill) on microstructural evolution and phases formed was evaluated. The variation of powder characteristics depending on the milling time was also investigated by $\mathrm{He}$ et al [9]. A pre-alloyed $\mathrm{Cr}_{3} \mathrm{C}_{2}-25(\mathrm{Ni20Cr})$ powder was mechanically milled in an attritor ball mill. However, the referred to studies kept the parameters BPR and milling speed constant. The aim of this study is to investigate the impact of different BPRs, milling times and milling speeds on the morphology of nanostructured $\mathrm{CrC}-30 \mathrm{wt} \% \mathrm{NiCr}$.

\section{Experimental Procedure}

A commercial carbide powder (CRC-410, Praxair Surface Technologies) with a nominal particle size of $-53+15 \mu \mathrm{m}$ was chosen for this study. The milling procedure was carried out at room temperature, using a planetary ball mill (Pulverisette 6 Fritsch). A tempered steel grinding bowl and AISI 52100 steel balls, $10 \mathrm{~mm}$ in diameter, were used. Ethanol was the milling medium used. Two ball-to-powder ratios - BPR (1:5 and 1:20), four milling times $(0.5,1,5$ and $10 \mathrm{~h})$ and two milling speeds (250 and $500 \mathrm{rpm}$ ) were used.

The crystalline phases and crystallite sizes were determined by a Phillips X'Pert MPD X-ray diffractometer with $\mathrm{Cu}-\mathrm{K} \alpha$ radiation $(\lambda=1.5406)$ operated at $40 \mathrm{kV}$ and $40 \mathrm{~mA}$. Crystallite size was determined by measuring the Bragg peak width at half maximum intensity and using the Scherrer formula (Equation 1):

$$
\beta=\frac{0,9 . \lambda}{D \cdot \cos \theta}
$$

Where $D$ is the crystallite size, $\beta$ is the pure broadening of the diffraction peak measured at half maximum intensity, $\lambda$ is the wavelength of the $\mathrm{X}$-ray radiation used and $\theta$ is the Bragg angle [10].

The average grain diameter of the composite particle was measured with a CILAS 1180 particle size analyzer. For microstructure examination, a JEOL-JSM 6060 scanning electron microscope (SEM) was used. 


\section{Results and Discussion}

The chemical composition of the starting powder is shown in Table 1. Figure 1 shows the morphology of the raw material. The morphology is predominantly spherical, which is characteristic of the fabrication process used (gas atomisation) [11]. Figure 2 shows the XRD diffractograms of as-received powder.

Table 1 - Chemical composition of $\mathrm{CrC}-30 w t \% \mathrm{NiCr}$ commercial powder (Praxair Surface Technologies).

\begin{tabular}{lccc}
\hline Element & $\mathbf{C r}$ & $\mathbf{N i}$ & $\mathbf{C}$ \\
\hline Composition (\%) & 88 & 8 & 4 \\
\hline
\end{tabular}

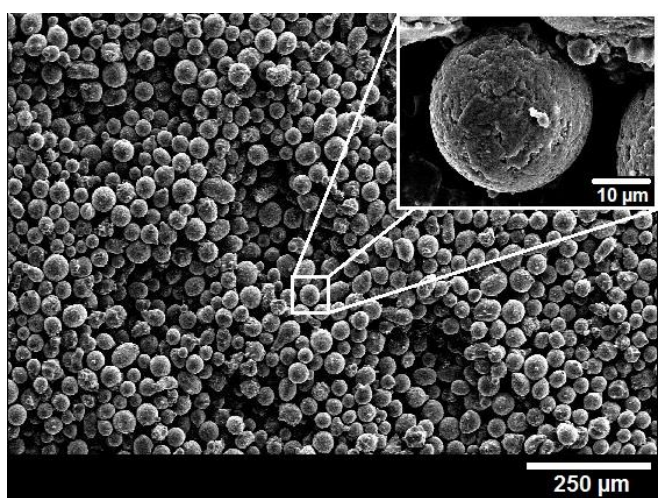

Figure 1 - SEM image of CrC-30wt $\% \mathrm{NiCr}$ powder as raw material.

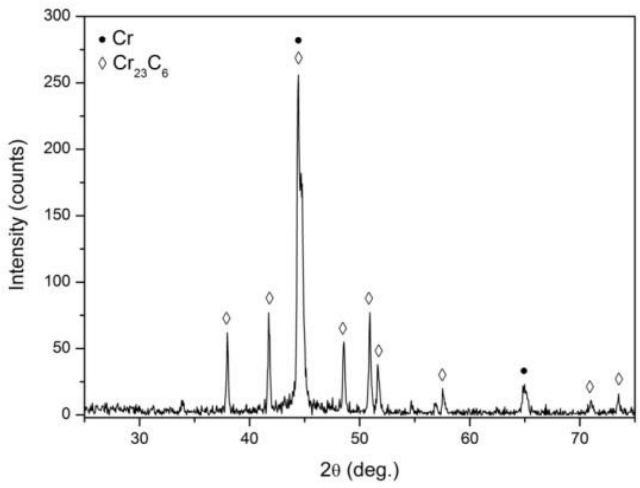

Figure 2 - X-ray pattern of $\mathrm{CrC}-30 \mathrm{wt} \% \mathrm{NiCr}$ as-received powder.

Figure 3 shows the $\mathrm{X}$-ray patterns of $\mathrm{CrC}-30 \mathrm{wt} \% \mathrm{NiCr}$ particles after ball milling by different BPR's and milling speeds. The presence of the $\mathrm{Cr}$ and $\mathrm{Cr}_{23} \mathrm{C}_{6}$ phases (JCPDS file 00-0011251 and JCPDS file 01-071-0552, respectively) can be identified. The $\mathrm{Cr}_{23} \mathrm{C}_{6}$ diffraction peaks can be masked by $\mathrm{Ni}$ peaks, because this phase occurs for 2theta values near the carbide phase [12]. After ball milling, the diffraction peaks broaden, as a result of reduction in crystallite size [3, 13]. A higher peak broadening can be observed for milling time of $10 \mathrm{~h}$ and milling speed of $500 \mathrm{rpm}$ (Figure $3 \mathrm{~b}$ and $\mathrm{d}$ ).
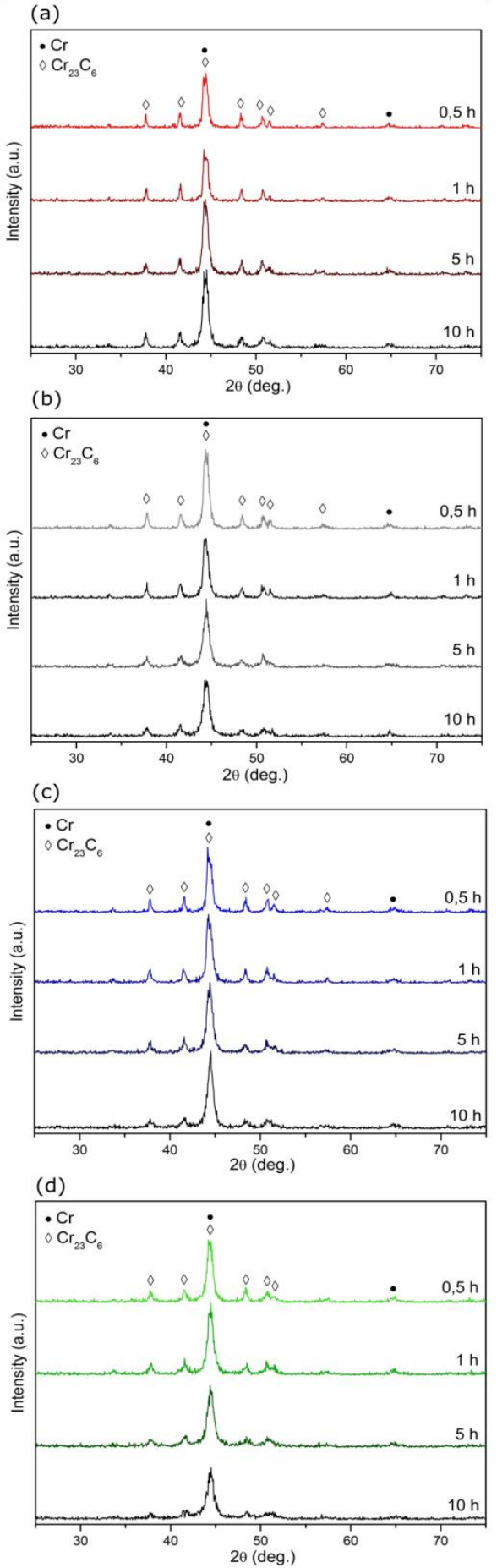

Figure 3 - X-ray patterns of $\mathrm{CrC}-30 \mathrm{wt} \% \mathrm{NiCr}$ particles after ball milling by different parameters: (a) 1:5 $250 \mathrm{rpm}$, (b) 1:5 $500 \mathrm{rpm}$, (c) 1:20 $250 \mathrm{rpm}$ and (d) 1:20 $500 \mathrm{rpm}$. 
Crystallite sizes of $\mathrm{CrC}-30 \mathrm{wt} \% \mathrm{NiCr}$ particles after ball milling are shown in Figure 4. Reduction in crystallite size can be observed as time, rotation speed and BPR increase. In case of a BPR of 1:20 and a milling speed of $500 \mathrm{rpm}$, a shorter milling time is required to get the lowest crystallite size values. This behavior is explained by the higher energy and frequency of impacts of the milling balls as a result of their higher speed [3]. The lowest crystallite size $(7.5 \mathrm{~nm})$ was obtained with a BPR of 1:20, milling speed of $500 \mathrm{rpm}$ and milling time of $10 \mathrm{~h}$.

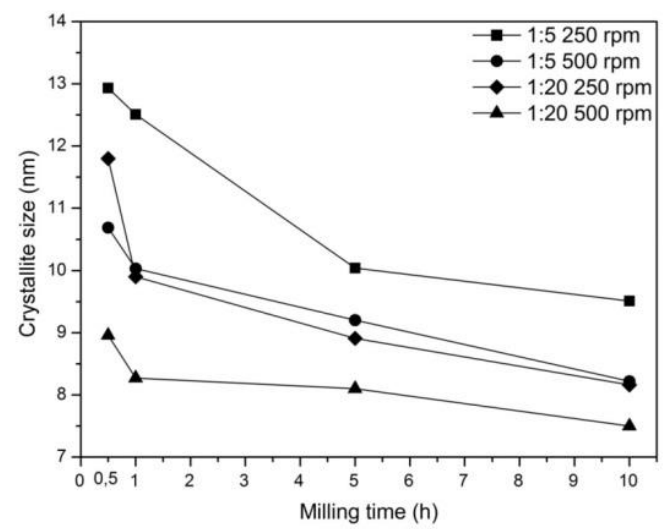

Figure 4 - Crystallite size of $\mathrm{CrC}-30 \mathrm{wt} \% \mathrm{NiCr}$ particles as a function of milling time, milling rotation speeds and ball-to-powder weight ratio.

Figure 5 shows the mean diameter variation as a function of the milling time for different milling parameters. The particle median size of the raw material is $43.10 \mu \mathrm{m}$. A significant reduction in particle size occurs after milling. The mean diameter was smaller for higher BPRs, milling times and speeds. Powders milled during $10 \mathrm{~h}$ showed smaller particle sizes. The lowest particle size $(3.99 \mu \mathrm{m})$ was obtained with a BPR of 1:20, milling speed of $500 \mathrm{rpm}$ and milling time of $10 \mathrm{~h}$.

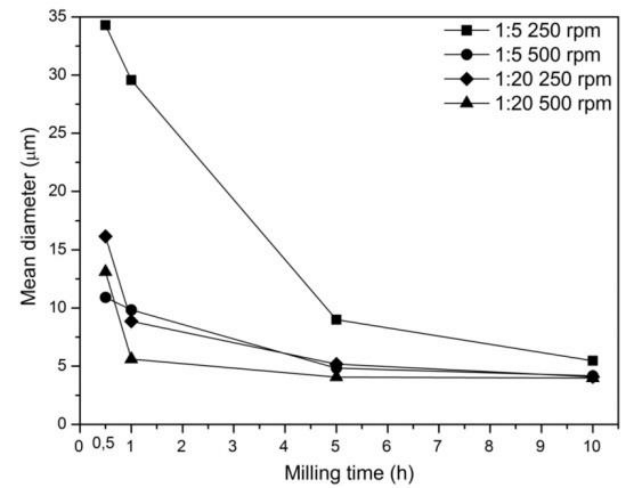

Figure 5 - Mean diameter of $\mathrm{CrC}-30 \mathrm{wt} \% \mathrm{NiCr}$ particles as a function of milling time, milling rotation speeds and ball-to-powder weight ratio.

Changes in the powder microstructure for samples processed with BPR of 1:20 and milling speed of $500 \mathrm{rpm}$ are shown in Figure 6. Particle size decreased with increased milling time. This is in accordance with the mean diameter and crystallite size values. We can also see that the particles lost their initial morphology, being fragmented into fine powder. (a)

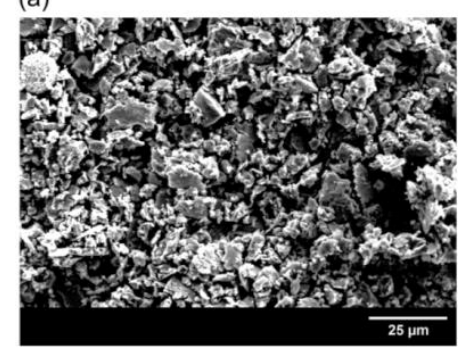

(c)

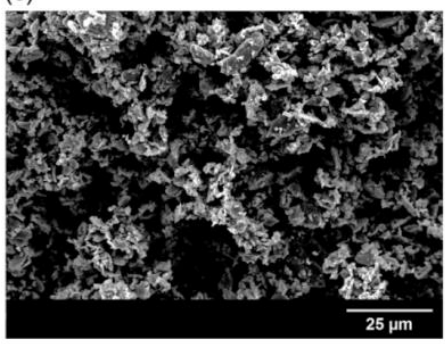

(b)

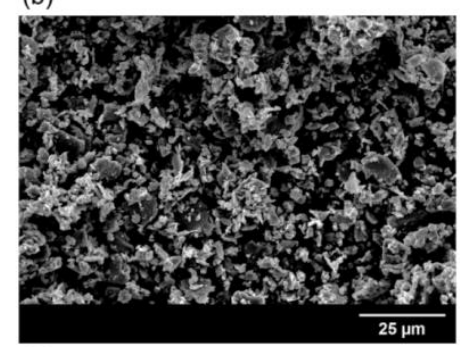

(d)

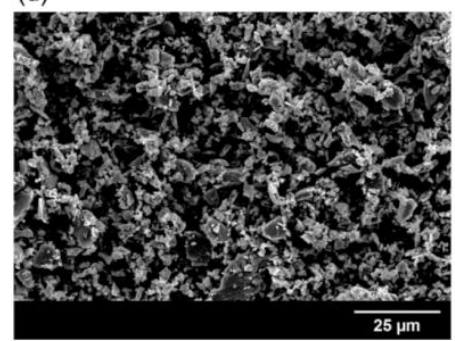

Figure 6 - SEM images of $\mathrm{CrC}-30 \mathrm{wt} \% \mathrm{NiCr}$ powders processed with $\mathrm{BPR}$ of 1:20, milling speed of 500rpm and milling time of $0.5 \mathrm{~h} \mathrm{(a)} ; 1 \mathrm{~h} \mathrm{(b)} ; 5 \mathrm{~h} \mathrm{(c)} \mathrm{and} 10 \mathrm{~h}$ (d).

\section{Conclusions}

Nanostructured $\mathrm{CrC}-30 \mathrm{wt} \% \mathrm{NiCr}$ was synthesized by high energy ball milling in a planetary ball mill. Changes in the powder morphology were observed due to milling parameters: ball to powder ratio (BPR), milling time and speed. We found that increase in BPR, milling time and speed reduced the crystallite size and mean diameter. Powders milled during $10 \mathrm{~h}$ presented smaller mean diameter and crystallite size than powders milled during a shorter period of time. However, for a BPR of 1:20 and a milling speed of $500 \mathrm{rpm}$, which are the highest BPR and milling speed tested, a shorter milling time is required to get the lowest values. After $1 \mathrm{~h}$ of milling, the crystallite size of the $\mathrm{CrC}-30 \mathrm{wt} \% \mathrm{NiCr}$ powder was reduced to $8.3 \mathrm{~nm}$, with a particle size of $5.6 \mu \mathrm{m}$.

\section{Acknowledgments}

The financial support of FAPERGS/CNPq PRONEX is gratefully acknowledged.

\section{INFLUÊNCIA DOS PARÂMETROS DE MOAGEM NA MORFOLOGIA DE CrC-30wt\% NiCr NANOSTRUTURADO}


RESUMO: Pós nanoestruturados de $\mathrm{CrC}-30 \mathrm{wt} \% \mathrm{NiCr}$ foram sintetizados por moagem de alta energia em um moinho planetário. Duas razões bolas/pó, quatro tempos de moagem e duas velocidades de moagem foram utilizadas. Morfologia, diâmetro médio de grão, e transformação de fases dos pós foram caracterizadas por microscopia eletrônica de varredura (MEV), análise de tamanho de partícula, e difração de raios-X (DRX). O tamanho de cristalito e o diâmetro médio diminuiram com o aumento da razão mássica bolas/pó, tempo e velocidade de moagem. Os resultados mostraram que utilizando razão mássica bolas/pó de 1:20, tempo de moagem de 1 hora e velocidade de moagem de $500 \mathrm{rpm}$, o tamanho de partícula e o tamanho de cristalito foram respectivamente $5,6 \mu \mathrm{m}$ e $8,3 \mathrm{~nm}$.

Palavras-chave: $\mathrm{CrC}-30 \mathrm{wt} \% \mathrm{NiCr}$. Nanoestruturado. Moagem de alta energia. Morfologia.

\section{References}

[1] MATTEAZI, P.; LE CAER, G.; Synthesis of nanocrystalline alumina-metal composites by room-temperature ball-milling of metal oxides and Aluminum. J Am Ceram Soc, Vol. 75, p. 2749-2755, 1992

[2] SURYANARAYANA, C.; Synthesis of nanocomposites by mechanical alloying. J Alloys Comp, Vol. 509S, p. S229-S234, 2011.

[3] SURYANARAYANA, C.; Mechanical alloying and milling. Progress Mater Sci., Vol. 46, p. 1-184, 2001.

[4] LÜ., L; LAI, M.O.; Mechanical Alloying; Springer US; New York, 1998. $276 \mathrm{p}$.

[5] SURYANARAYANA, C.; Mechanical Alloying and Milling; CRC Press; New York, 2004. 488p.

[6] SURYANARAYANA, C.; AL-AQEELIB, N.; Mechanically alloyed nanocomposites. Progress Mater Sci, Vol. 58, p. 383-502, 2013.

[7] TAO, K.; ZHOU, X.L.; CUI, H.; CHEN, H.B.; LI, Y.B.; ZHANG, J.S.; Synthesis of nanocrystalline $\mathrm{NiCrC}$ alloy feedstock powders for thermal spraying by cryogenic ball milling. Intern J Min Metall Mater, Vol. 16, p.77-83, 2009.

[8] HUANG, H.; McCORMICK, P.G.; Effect of milling conditions on the synthesis of chromium carbides by mechanical alloying. J Alloys Comp, Vol. 256, p. 258-262, 1997.

[9] HE, J.; ICE, M.; LAVERNIA, E.J.; Synthesis and characterization of nanostructured Cr3C2-NiCr. Nanostruct Mater, Vol. 10, p. 1271-1283, 1988.

[10] CULLITY, B.D.; Elements of X-ray Diffraction.; Addison-Wesley; Massachusetts; 1956. 656p.

[11] PRAXAIR SURFACE TECHNOLOGIES. Disponível em: http://www.praxairsurfacetechnologies.com/components-materials-andequipment/materials/thermal-spray-powders/carbide. Acesso em 06/09/2016.

[12] VICENZI, Juliane. Relação entre microestrutura e erosão (a frio e a quente) de revestimentos do sistema $\mathrm{NiCr}-\mathrm{Cr} 3 \mathrm{C} 2$ obtidos por aspersão térmica. 2007. 304f. Thesis (PPGE3M) - Federal University of Rio Grande do Sul, Porto Alegre. 2007.

[13] HE, J.; SCHOENUNG, J.M. Nanostructured coatings. Materials Science and Engineering A, Vol. 336, p. 274-319, 2002. 